\title{
Plastic surgery professional misconduct: a cross-sectional study on cases between 2008 and 2017, filed before the São Paulo State Medical Board
}

\author{
Paulo Cézar Mariani', Clóvis Francisco Constantino", Rui Nunes"II \\ Conselho Regional de Medicina de São Paulo (CREMESP), São Paulo (SP), Brazil
}

'MD. Doctoral Student, Faculdade de Medicina da Universidade do Porto, Porto, Portugal. (iD https://orcid.org/0000-0002-9576-5510

"PhD. Physician and Professor, Universidade de Santo Amaro (UNISA), São Paulo (SP), Brazil. (D) https://orcid.org/0000-0002-7540-2632

I'PhD. Professor, Faculdade de Medicina da Universidade do Porto, Porto, Portugal. (D) https://orcid.org/0000-0002-1377-9899

KEY WORDS (MeSH terms):

Process assessments, health care. Ethics, medical.

Surgery, plastic.

AUTHORS' KEY WORDS:

Professional-misconduct cases. Medical ethics.

Medical board investigations

\begin{abstract}
BACKGROUND: In plastic surgery, a lack of ethical and moral behavior by professionals can result in unfortunate circumstances and can justify ethical-disciplinary procedures.

OBJECTIVE: To review 421 plastic surgery professional-misconduct cases filed before the São Paulo State Medical Board (CREMESP) between 2008 and 2017.

DESIGN AND SETTING: Cross-sectional study conducted in a medical council.

METHODS: The cases were categorized according to sex, age, medical specialty (plastic surgery, other field or none), medical ethics code chapter(s) involved, ethics code articles violated and board ruling/outcome. RESULTS: Most of the defendants were men over 40 years of age who were experienced in their professional practice and who graduated from public and private universities all over Brazil; $47.74 \%$ had a specialist title in plastic surgery. Violation of professional responsibility (medical malpractice, recklessness or negligence) was the commonest complaint (28.43\%), followed by medical advertising (24.19\%) and poor doctor-patient relationship (10.39\%), in violation of articles 18, 51, 75 and 1. Among the 233 cases adjudicated over this period, 133 resulted in disciplinary sanction, 80 were ruled in the physician's favor and 20 were dismissed.

CONCLUSION: Classification of plastic surgery professional-misconduct cases creates possibilities for adopting preventive measures for good practice in this specialty, which would consequently reduce the number of complaints to the regional medical boards.
\end{abstract}

\section{INTRODUCTION}

Plastic surgery is a medical procedure that consists of various surgical or non-surgical procedures that reshape human body parts. The purpose is to treat "anatomical, congenital, acquired, post-traumatic, degenerative and oncological deformities to improve patients' biopsychosocial health and subsequently their quality of life". ${ }^{1}$

Borges ${ }^{1}$ reported that there had been an explosive increase in lawsuits involving plastic-surgery malpractice, which has led to challenges for physicians and medical associations. Two phenomena explain this considerable increase in lawsuits: on the one hand, patients are increasingly more aware of their rights enshrined in articles 196 and 200 of the Brazilian Constitution, including redress for medical malpractice; and on the other hand, patients are clearly being affected by job instability, especially in the government, and by media influence, deteriorating doctor-patient relationships and inefficient university residency and postgraduate programs. These issues have led to greater legislative protections for patients seeking answers for care or treatment that was deemed unsatisfactory. ${ }^{2}$

Physicians commit ethical violations when they fail to follow medical guidelines. ${ }^{3-6}$ Therefore, civil liability for medical malpractice should be examined from two separate angles: a) liability for services directly and personally rendered by physicians as self-employed individuals; b) medical liability for rendering medical services as a business, which includes inpatient and outpatient hospitals, clinics, blood banks and medical laboratories. ${ }^{7,8}$

In medical practice, malpractice is understood as a wrongful act that damages or jeopardizes the health of another person and occasions poor or adverse result(s) owing to a physician's action 
or inaction, in violation of medical guidelines. ${ }^{9-11}$ Malpractice can be qualified by any of the three types listed in article 1 of the medical ethics code, based on the Brazilian penal code, the Brazilian constitution or the Brazilian civil procedure code, namely negligence, recklessness and professional malpractice.

The article governing professional responsibility is the article most often violated by doctors. ${ }^{12}$ The Brazilian Medical Association (BMA) and regional medical boards are tasked with being notified of, investigating and ruling on all complaints filed, as well as for regulating the practice of medicine. ${ }^{13-15}$ Once a professional-misconduct case has been instituted, and once it has been established that there has been a violation of the medical ethics code, any of the five disciplinary sanctions listed in article 22 of Brazilian law 3.268/1957 can be handed down to the physician: confidential warning - classified notice (punishment A); confidential reprimand - classified notice (punishment $\mathrm{B}$ ); public reprimand notice on public record (punishment $\mathrm{C}$ ); suspension of license to practice for up to 30 days (punishment $\mathrm{D}$ ); or revocation of license to practice pending final ruling by the Brazilian Medical Association (punishment E). Either party may appeal against any punishment administered. ${ }^{16,17}$

\section{OBJECTIVE}

The objective of this study was to classify cases relating to plastic surgery professional misconduct filed before the São Paulo State Medical Board (CREMESP) between 2008 and 2017, considering the demographic and professional characteristics: sex, age, private or public university education, medical specialty (plastic surgery, other field or none); and the case characteristics: medical ethics code chapter involved in the case, ethics code article(s) violated and ruling/outcome.

\section{METHODS}

This was a retrospective cross-sectional database study that included all professional-misconduct cases involving plastic surgery that were filed before CREMESP over a 10-year period from 2008 to 2017. A total of 421 such cases were investigated (and closed) by CREMESP over this period. Notably, among these 421 cases, there were physicians under investigation in more than one case, such that 273 physicians, with or without a specialty qualification in plastic surgery, were involved.

We analyzed complaints involving plastic surgery in the CREMESP database after firstly receiving authorization from CREMESP (through a letter from its board, without reference number, but dated September 12, 2017) and then receiving ethics approval from the research ethics committee of the university where this study was conducted (no. 2.338.983; dated October 19, 2017). The board furnished the research team only with complaints involving plastic surgery, and the parties to the complaints were not identified. This research was conducted in accordance with the ethical and care standards and set forth in the Declaration of Helsinki and Nuremberg Code (Brazilian Medical Association Ruling 1785/2006). Professional-misconduct cases that had been dismissed or that were converted to administrative proceedings were not included.

The following variables were extracted from the database: sex, age, possession of medical specialty title in plastic surgery, case subject matter, medical ethics code article(s) violated and ruling/outcome.

The quantitative research design was descriptive, in accordance with the nature of the variable. The results are presented in tables, as described below.

\section{RESULTS}

A total of 7,789 professional-misconduct cases of all natures were filed before CREMESP during the period in question. Of these, 421 cases $(5.40 \%)$ involved 273 physicians with or without a specialty qualification in plastic surgery. All regional-board cases filed or pending before the CREMESP between 2008 and 2017 were included in the present review.

At the time of this review, among the 421 professional-misconduct cases that met the inclusion criterion, 233 (55.35\%) cases had been adjudicated. Of these 233 cases, 133 (57\%) resulted in disciplinary sanction, 80 (34.5\%) were ruled in the physician's favor and $20(8.5 \%)$ were dismissed. A total of 188 cases (44.65\%) were still pending investigation and judgment at the end of the year 2017, when data were collected for this review.

\section{Classification of defendants}

Table 1 lists the general characteristics of the defendant physicians: sex, age, type of university education and whether they had a medical specialty title in plastic surgery.

The average age of the physicians accused of misconduct was 49.5 years. The youngest was 30 years old and the oldest, 73 years old. The majority ( $58.43 \%$ ) were younger than 50 years at the time when the complaint was filed. Most of the defendants had received their medical degrees from private universities and were not specialists in plastic surgery.

Table 2 shows the breakdown of all the physicians without a specialty title in plastic surgery who were accused of medical misconduct, namely: physicians with a medical specialty other than physical surgery; and physicians bearing no record of any medical specialty.

Among the 421 cases, 201 cases (47.74\%) were brought against specialists in plastic surgery, 147 cases $(34.91 \%)$ were brought against physicians who were not licensed in any specialty and 73 cases $(17.34 \%)$ were brought against physicians who were licensed as medical specialists in fields other than plastic surgery. 
Table 1. Breakdown of the 421 cases according to sex, age, type of university education, and possession of a specialty title in plastic surgery, in numbers and percentages

\begin{tabular}{|c|c|c|}
\hline Physician profile & n & $\%$ \\
\hline \multicolumn{3}{|l|}{ Sex } \\
\hline Male & 325 & 77.19 \\
\hline Female & 96 & 22.81 \\
\hline Total & 421 & 100.00 \\
\hline \multicolumn{3}{|l|}{ Age (years) } \\
\hline $30-39$ & 109 & 25.89 \\
\hline $40-49$ & 137 & 32.54 \\
\hline $50-59$ & 85 & 20.19 \\
\hline $60-69$ & 56 & 13.30 \\
\hline$>70$ & 34 & 8.08 \\
\hline Total & 421 & 100.00 \\
\hline \multicolumn{3}{|l|}{ University type } \\
\hline Public & 175 & 41.57 \\
\hline Private & 246 & 58.43 \\
\hline Total & 421 & 100.00 \\
\hline \multicolumn{3}{|c|}{ Plastic surgery specialty } \\
\hline Yes & 201 & 47.74 \\
\hline No & 220 & 52.26 \\
\hline Total & 421 & 100.00 \\
\hline
\end{tabular}

Table 2. Distribution of the numbers of physicians without a specialty title in plastic surgery who were accused of medical misconduct, including physicians with a medical specialty other than plastic surgery and physicians with no record of any medical specialty, in numbers and percentages

\begin{tabular}{lcc}
\multicolumn{2}{c}{$\begin{array}{c}\text { Distribution of physicians without a } \\
\text { specialty title in plastic surgery }\end{array}$} & \\
\hline Other specialties & $\mathbf{n}$ & $\%$ \\
\hline Anesthesiology & 17 & 7.72 \\
\hline Angiology/vascular surgery & 1 & 0.45 \\
\hline Oncology & 1 & 0.45 \\
\hline General surgery & 1 & 0.45 \\
\hline Vascular surgery & 1 & 0.45 \\
\hline Internal medicine & 1 & 0.45 \\
\hline Internal medicine - endocrinology and & 1 & 0.45 \\
metabolic health & & \\
\hline Dermatology & 23 & 10.45 \\
\hline Endocrinology and metabolic health & 1 & 0.45 \\
\hline Obstetrics and gynecology & 5 & 2.27 \\
\hline Homeopathy - pediatrics & 2 & 0.91 \\
\hline Family medicine and community health & 1 & 0.45 \\
\hline Occupational health & 3 & 1.36 \\
\hline Clinical nutrition & 1 & 0.45 \\
\hline Ophthalmology & 2 & 0.91 \\
\hline Orthopedics & 5 & 2.27 \\
\hline Otorhinolaryngology & 6 & 2.73 \\
\hline Pathology & 1 & 0.45 \\
\hline No record of any specialty & 147 & 66.88 \\
\hline Total & $\mathbf{2 2 0}$ & $\mathbf{1 0 0 . 0 0}$ \\
\hline & & \\
\hline
\end{tabular}

\section{Classification of complaints}

Table 3 lists the medical ethics code chapters (subject/topic) cited in the 421 cases. The most frequent subject/topic cited in these cases brought between 2008 and 2017 was violation of professional responsibility (medical malpractice, recklessness or negligence) (79.10\%), followed by doctor-doctor relationships (complaints filed by fellow physicians) (52.49\%) and then by professional confidentiality (34.67\%).

The medical ethics code articles most often violated were articles 18 (35.82\%), 51 (27.45\%), 75 (20.22\%) and 1 (16.51\%). These are all deontological articles referring to professional responsibility, doctor-doctor relationships and professional confidentiality.

Among the cases filed over the study period, 233 cases (55.35\%) had been adjudicated by the end of the year 2017, when data were collected for this review. The other 188 cases remained pending, awaiting the board's ruling. Among the 233 adjudicated cases, 133 (57\%) resulted in disciplinary sanction and 80 (34.5\%) were ruled in the physician's favor.

Table 4 shows the distribution of disciplinary sanctions taken in the 133 cases in which the physician was found guilty, with a breakdown according to sex, age, type of medical university and possession of a specialist title in plastic surgery.

It was observed that male physicians were most often sanctioned with punishment B (35.95\%), while female physicians were most often sanctioned with punishment C (43.33\%). Regardless of the type of punishment, male physicians in general faced more punishment than female physicians. With regard to age group, physicians aged 30-39 years were most likely to be administered punishment C (77.50\%), physicians aged 40-49 were most likely to be administered punishment B (62.96\%), physicians aged 60-69 were most likely to be administered punishment A (58.33\%) and physicians aged 70 and older were most likely to be administered punishment E (75.00\%). Also, punishment $\mathrm{C}$ was most applied to doctors aged 30-39 (the youngest cohort), and punishment $\mathrm{E}$ was most applied to doctors aged 70 and over (the oldest cohort).

Table 3. Distribution of medical ethics code chapters (subject/topic) cited in the 421 cases, in numbers (occurrences) and percentages

\begin{tabular}{lcc}
\multicolumn{3}{c}{ Breakdown of medical ethics code subjects/topics cited } \\
\hline Ethics code subjects and topics & Occurrences & $\%(\mathbf{n}=\mathbf{4 2 1})$ \\
\hline Professional responsibility & 333 & 79.10 \\
Human rights & 95 & 22.56 \\
\hline Doctor-patient relationship & 100 & 23.75 \\
\hline Doctor-doctor relationship & 221 & 52.49 \\
Professional remuneration & 132 & 31.35 \\
\hline Professional confidentiality & 146 & 34.67 \\
Medical documents & 141 & 33.49 \\
Teaching and medical research & 03 & 0.71 \\
Medical advertising & 137 & 32.54
\end{tabular}


Table 4. Breakdown of disciplinary sanctions taken in the 133 cases in which physicians were found guilty, with a breakdown by sex, age, type of medical university, and specialty title in plastic surgery status, in numbers and percentages

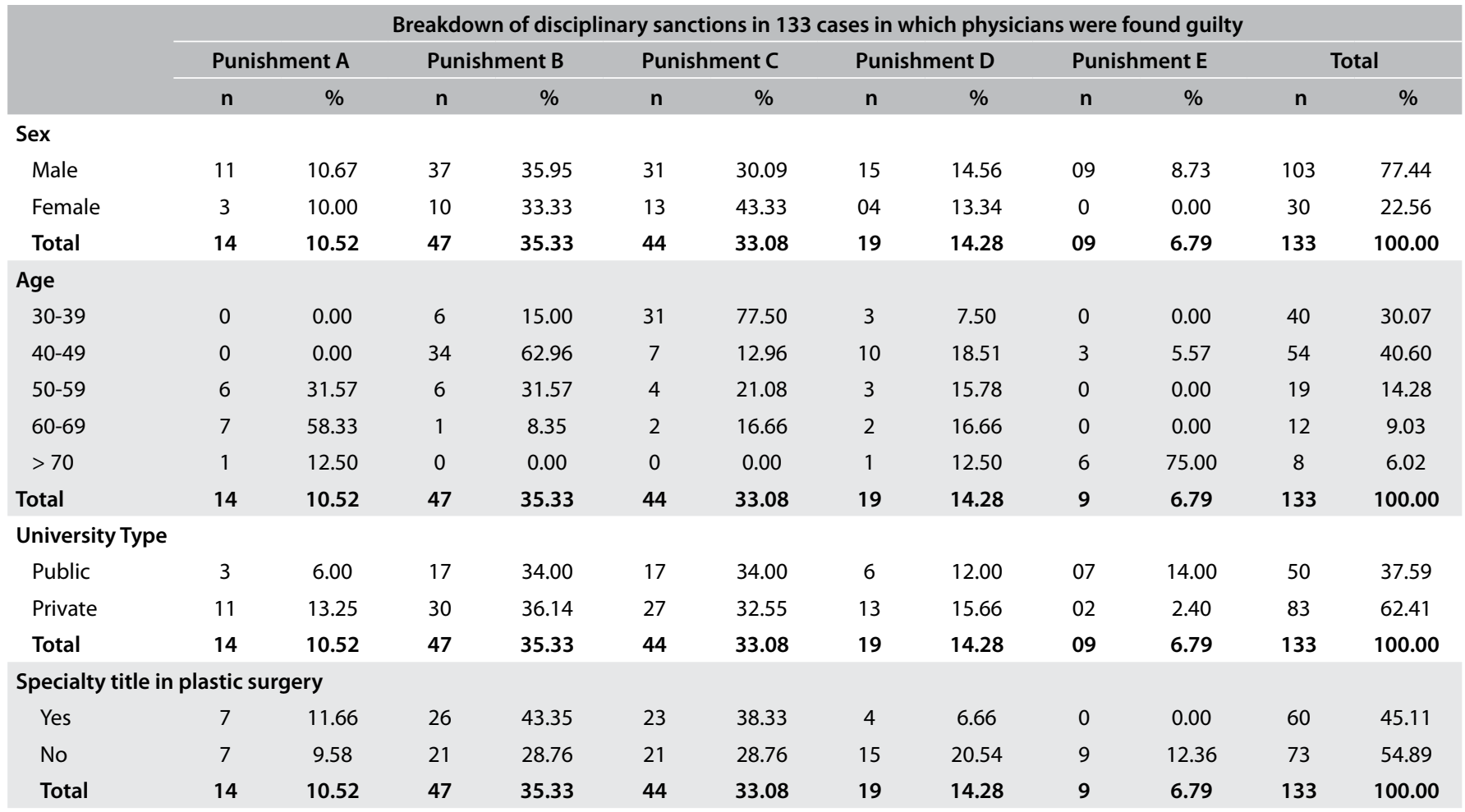

Regarding university type, physicians who studied at a private institution were more likely to face disciplinary sanction (62.41\%) than were those who studied at public institutions (37.59\%). Regardless of the type of institution, punishments B and C were administered most frequently.

Physicians without a medical specialty title in plastic surgery were more likely to face disciplinary sanction (54.89\%) than were those who were specialists in plastic surgery. However, in looking more closely at the punishments applied to those with a specialty title in plastic surgery, punishments B and C (43.35\% and 38.33\% respectively) are seen to be most prevalent.

\section{DISCUSSION}

\section{Sex}

Out of the 273 physicians involved in the 421 cases analyzed here, $77.19 \%$ were male, a finding that is consistent with other studies. ${ }^{16,18}$ It was noted that complaints were brought against male physicians and that male physicians were found guilty of misconduct three times more often than was observed among female physicians.

Carvalho ${ }^{19}$ reported that complaints were filed less frequently against female physicians because they interacted more with patients, spent more time listening to them during examinations, saw fewer patients overall and treated patients with less serious conditions or complaints. In other words, women were perceived to be better at interacting, listening, talking and explaining, and they seemed to be more attentive as well. Despite the physician-physician relationship, this may explain the comparatively low number of complaints filed with regional medical boards against female physicians, compared with male physicians.

\section{Age}

The average age of the physicians accused of misconduct was 49.5. The age range in which the greatest number of physicians was found guilty was the 40 to 49 -year-old group (40.60\%), while the oldest group (70+ years old) was the age group found guilty least often $(6.02 \%)$.

These numbers referred to physicians who had been licensed for about 10 years and who were, therefore, in their most productive phase. At this time in their careers, they undertake a large volume of medical procedures, with high number of complex surgeries, while experiencing a time of greater financial demand relating to family and personal responsibilities.

The average age range of the physicians accused of misconduct, namely 40-49 years old, was consistent with the findings. ${ }^{20-22}$ This symmetry corroborates the results of this study. 


\section{Medical specialty title in plastic surgery}

This study shows that 220 of the cases in which complaints were filed (52.26\%) were against physicians who were not medical specialists in plastic surgery. Brazilian law allows doctors to perform any procedure provided that they possess the requisite technical knowledge. ${ }^{10}$ Physicians licensed for other specialties are performing plastic surgeries for which they are not prepared, which increases patient risk. One study conducted by CREMESP in 2008 showed that $97 \%$ of the cases of mistakes (or misconducts) in plastic surgeries were filed against physicians who did not possess a specialist title in plastic surgery. ${ }^{23}$

In Brazil, given the shortage of residency places and given the personal need to begin working, it is common for physicians to begin practicing internal medicine and to informally practice plastic surgery. They may occasionally obtain a license in plastic surgery, following a review of their knowledge and experience by the medical association. ${ }^{24}$

It can be noted that a generalist profile is very common among physicians in small towns, while in big cities there is greater demand for specialized professionals.

Standardization of care, through better regulation and standards regarding medical specialization, is needed to ensure patient safety and to provide back-up for patients' options in choosing a licensed plastic surgeon. ${ }^{25}$

\section{Medical ethics code chapters (subject/topic)}

Violation of professional responsibility (medical malpractice, recklessness or negligence) was the most common complaint. This result is consistent with published data. ${ }^{12}$

The existence of complaints of negligence, medical malpractice or recklessness makes it clear that most mistakes or misconducts that occur in the practice of plastic surgery are due to physicians' omissions or passiveness in relation to patients who should be receiving more attention and care. This is corroborated by the rate of cases found in physicians' favor on account of a lack of evidence to back up the complaints. ${ }^{21}$

However, the general understanding is that it is legally permitted to practice medicine provided that the physician meets the legal and professional licensing requirements. It is illegal to practice medicine with any degree of recklessness, malpractice or negligence. When recklessness, medical malpractice or negligence occurs, Brazilian law calls for redress and punishment and establishes that damages should be awarded to the patient(s) harmed. In these situations, culpability is generally and usually attributed to the physician. Advances in medical science have led to greater medical responsibility, and, in this light, physicians are now liable for greater risks and for a greater number of possible accidents, which may be grounds for a discussion on culpability lying outside of physicians' purview. ${ }^{26}$
Physicians filing complaints against their colleagues was the second most common plastic-surgery-related complaint filed (doctor-doctor relationship). The medical ethics code explicitly lists medical professionals' rights and duties. Although it may seem unethical to file a complaint against a fellow physician, situations in which colleagues fail, through omission or commission, to honor the medical ethics code give rise to a duty among physicians to report their colleagues' conduct to the regional medical board. The medical ethics code seeks to safeguard professional relationships. ${ }^{27}$

The problems that physicians may face in relation to their colleagues fall into two types: interpersonal matters like a lack of communication, cooperation or harmony; and professional matters like anti-ethical self-promotion or publicizing of "foolproof" methods and innovative and exclusive techniques, etc. Such violations consequently lead to a breakdown of trust among physicians and weaken professional relationships, as stated in the medical ethics code of 2009. It is therefore important that physicians do file complaints before the regional medical board so that it can investigate any violations of the code. Since these complaints are considered to be administrative cases, physicians need not be wary of filing complaints; by bringing cases to the board's attention, they are fulfilling their civic duty.

In relation to professional confidentiality, a distinction is made between ethics and morality. Confidentiality has always been the moral obligation of professionals working in the field of medicine. Morality, like confidentiality, involves principles that guide a given behavior, while ethics consists of philosophical discussions for critical evaluation of morality and professional confidentiality. Therefore, ethics is a treatise within morality, dealing with values on scales from good to bad and from right to wrong. It needs to be noted that, despite the existence of a moral compass in the medical profession that is codified through rules to guide proper behavior, some physicians do not follow this and fail to respect confidentiality between doctors, patients and family information.

\section{Medical ethics code articles most commonly violated}

This study showed that the four most commonly violated ethics code articles among those in effect when the complaints were filed were 18, 51, 75 and 1. Article 18 ("Disobeying or disrespecting Brazilian Medical Association (CFM) or regional medical council rulings or appellate decisions") was cited most often in a previous study on complaints and cases against physicians who were found guilty and received punishment; those findings are corroborated by the results from the present study. ${ }^{28}$ Article 51 ("Engaging in unfair competition with another physician") primarily relates to self-promotion. Article 75 ("Making reference to identifiable clinical cases or exposing patients or their profiles in medical advertisements, medical publications or the media in 
general without patient consent") is most often found in marketing and advertising involving pre and postoperative patient photos. Lastly, article 1 ("Causing harm to the patient, through omission or commission, characterized by medical malpractice, recklessness or negligence") is referred to collectively in the present paper as "professional misconduct". 29

Although medical advertising was not the subject of the majority of the complaints filed during the period of the present study, all four of the aforementioned articles involve medical advertising to some degree, as explained in a previous study. ${ }^{30}$ In plastic surgery, medical advertising strongly influences the mistake or misconduct identified. Profiting from the profession through marketing of medicine is considered to be unethical behavior. In this vein, physicians are not allowed to be party to any commercials or advertisements that in any way promote or profit from the profession. Regardless of the specialty, physicians should not guarantee results or treatment. Physicians must clearly inform patients of the benefits and risks of a given procedure. Advertising in which physicians publicize simple and quick treatment that is $100 \%$ effective is an invitation for lawsuits to hold physicians to the purported results. Promising results put the physician in a delicate situation, since complications may arise during treatment. Medical information should include what is scientifically correct and accepted as good medical practice, and medical professionals should base their practice on the laws that are in effect.

\section{Disciplinary sanctions}

Our review of the disciplinary sanctions taken showed that punishment B (confidential reprimand - classified notice) was the punishment most often administered. This finding speaks to one of CREMESP's maxims, namely that professional-misconduct cases are meant to serve as a means for educating physicians. There is generally no reason to put the ruling or sanctions imposed into the public record, except in cases in which the situation is grave, or in cases of repeated offense and cases in which there is imminent indisputable risk or harm to others. These findings are similar to previous findings regarding the prevalence of confidential disciplinary sanctions. ${ }^{16-31}$

The data shows that punishment $\mathrm{C}$ was applied most to doctors aged 30-39 (the youngest group), and punishment E was applied most to doctors aged 70 and over (the oldest group).

It is not surprising that a punishment of public record was applied most to doctors in the 30-39-year-old cohort. Physician behavior at this age perfectly explains this phenomenon. The heavy workload facing the youngest group means that there is greater likelihood of facing a complaint. Moreover, self-confidence and possible consequent carelessness explain complaints filed against the oldest group. This supports similar findings that negligence was the complaint most often cited, reported in some previous studies. ${ }^{21,22}$
Physicians without a medical specialty title in plastic surgery were more likely to face disciplinary sanction (54.89\%) than those who were specialists in plastic surgery. However, looking more closely at the punishments applied to those with a specialty in plastic surgery, punishments B and C (43.35\% and 38.33\% respectively) were seen to be most prevalent. Greater severity of disciplinary sanctions for certain violations shows the existence of concern regarding where the field of medicine is heading and, primarily, concern regarding safeguarding society from medical malpractice, which is the raison d'etre of the regional medical boards.

\section{CONCLUSION}

The classification of physicians against whom plastic surgery medical misconduct cases were filed before the São Paulo State Medical Board (CREMESP) that was presented in this study was similar to what has been shown elsewhere in the medical literature. Physicians of all medical specialties, including plastic surgeons, are aware that medical practice nowadays is replete with many ethical assumptions and bioethical dilemmas stemming from new technologies and procedures. This demands deeper ethical reflection before making medical decisions. Medical misconduct due to negligence has become more rigorously punished on ethical grounds, both in Brazil and internationally.

\section{REFERENCES}

1. Borges G. Erro médico nas cirurgias plásticas. São Paulo: Editora Atlas; 2014.

2. Gonçalves ELN, Silva FCL. A especialidade médica e a construção da ética profissional: análise de 966 denúncias ao CRM/MG, no período de 2012 a 2017 [Medical specialty and the construction of professional ethics: analysis of 966 complaints to CRM/MG, from 2012 to 2017]. Temas em Saúde. 2020;20(1):162-77. http://doi.org/10.29327/213319.20.1-11.

3. Antonio EM, Fontes TM. A ética médica sob o viés da bioética: o exercício moral da cirurgia [Medical ethics under the bioethics' point of view: the moral surgical practice]. Rev Col Bras Cir. 2011;38(5):355-60. PMID: 22124649; https://doi.org/10.1590/S0100-69912011000500013.

4. BeauchampTL, Childress JF. Principles of biomedical ethics. $7^{\text {th }}$ ed. New York: Oxford University Press; 2013.

5. Nunes R. Ensaios em Bioética. Brasil: Conselho Federal de Medicina/ Faculdade de Medicina da Universidade do Porto; 2017. Available from: https://goo.gl/AZ7RJM. Accessed in 2021 (Jan 13).

6. Araújo AOV, Araújo DD, Nogueira AHAS, et al. Julgamento ético no Rio Grande do Norte entre 2000 e 2015. Rev. Bioét. 2020;27(4):739-46. http://dx.doi.org/10.1590/1983-80422019274357.

7. Benacchio M. Responsabilidade civil do médico: algumas reflexões. In Nery RMA, Donnini R (Coord.). Responsabilidade civil: estudos em homenagem ao Professor Rui Geraldo Camargo Viana. São Paulo: Revista dos Tribunais; 2009 
8. Alvarenga MAFP, Assis FS. A responsabilidade civil do cirurgião plástico nas cirurgias estéticas. Rev Eletrôn Faculd Dir Franca. 2013;7(1):222-41. https://doi.org/10.21207/1983.4225.214.

9. Kohn LT, Corrigan JM, Donaldson MS (Editors). To err is human: building a safer health system. Washington: National Academy Press; 2000

10. Conselho Federal de Medicina. Código de ética médica: resolução CFM no 1.931, de 17 de setembro de 2009 (versão de bolso)/ Conselho Federal de Medicina. Brasília: Conselho Federal de Medicina; 2010.

11. Gomes TR, Sá MCDNP. O erro médico sob o olhar do Judiciário: uma investigação no Tribunal de Justiça do Distrito Federal e Territórios. Cad Ibero-Am Direito Sanit. 2017;6(1):72-85. http://doi.org/10.17566/ ciads.v6i1.362.

12. Mariani PC, Constantino CF, Nunes R. Classification of plastic surgery malpractice complaints brought before the São Paulo Medical Board that were treated as professional-misconduct cases: a cross-sectional study. São Paulo Med J. 2020;138(2):140-5. PMID: 32159603; https:// doi.org/10.1590/1516-3180.2019.0363.09122019.

13. Silva JAC, Brito MVH, Oliveira AJB, et al. Sindicâncias e processos éticoprofissionais no Conselho Regional de Medicina do Pará: evolução processual no período de 2005 a 2007. Rev Bras Clin Med. 2010;8:20-4. Available from: http://files.bvs.br/upload/S/1679-1010/2010/v8n1/ a005.pdf. Accessed in 2019 (Sep 10)

14. Maia DB, Figueiredo Neto JA, Abreu SB, Silva DSM, Brito LMO. Perfil dos processos por erro médico em São Luís - Maranhão. Rev Pesq Saúde. 2011;12(2):18-22. Available from: http://www.periodicoseletronicos. ufma.br/index.php/revistahuufma/article/view/1044. Accessed in 2020 (Jan 13).

15. Gracindo GCL. Princípios bioéticos na prática médica no Brasil: construindo um perfil do profissional da Medicina a partir dos processos ético-disciplinares julgados (período 2010 - 2016), com base no atual Código de Ética Médica [thesis]. Porto: Universidade do Porto, Faculdade de Medicina; 2018

16. Bitencourt AGV, Neves NMBC, Neves FBCS, Brasil ISPS, Santos LSC. Análise do erro médico em processos ético-profissionais: implicações na educação médica [Medical error analysis in ethics investigations: implications on medical education]. Rev Bras Educ Med. 2007;31(3):2238. http://doi.org/10.1590/S0100-55022007000300004.

17. Santos MFO, Souza EHA, Fernandes MGM. Perfil dos médicos envolvidos em processos ético-profissionais - Paraíba 1999 a 2009 [Profile of physicians involved in ethical - professional processes - Paraiba 1999 to 2009]. Rev Bioét. 2011;19(3):787-97. Available from: https:// revistabioetica.cfm.org.br/index.php/revista_bioetica/article/view/620. Accessed in 2020 (Jan 13).

18. Koeche LG, Cenci I, Bortoluzzi MC, Bonamigo EL. Prevalência de erro médico entre as especialidades médicas nos processos julgados pelo Conselho Regional de Medicina do Estado de Santa Catarina [Prevalence of medical error among medical specialties in the Regional Medical Council of the State of Santa Catarina]. Arq Catarin Med. 2013;42(4):45-
53. Available from: http://www.acm.org.br/revista/pdf/artigos/1257. pdf. Accessed in 2020 (Jan 13).

19. Carvalho JMM. Erro médico: perfil profissional [dissertation]. Florianópolis: Universidade Federal de Santa Catarina; 2008.

20. França GV, Gomes JCM. Erro médico: um enfoque sobre sua origem e suas consequências. Montes Claros: Universidade de Montes Claros; 2000.

21. Constantino CF. Reflexão bioética e deontológica relacionada às denúncias e processos ético-profissionais envolvendo médicos que exercem pediatria no estado de São Paulo - Brasil [thesis]. Faculdade de Medicina da Universidade do Porto -FMUP/Portugal, Conselho Federal de Medicina-CFM/Brasil; 2013.

22. Ribeiro DTA. Estudo Bioético das Denúncias contra Médicos no Conselho Regional de Medicina do Estado do Acre - Brasil [thesis]. Faculdade de Medicina da Universidade do Porto-FMUP/Portugal, Conselho Federal de Medicina-CFM/Brasil; 2017.

23. Conselho Regional de Medicina do Estado de São Paulo. Cirurgia Plástica: 97\% dos médicos processados não têm título de especialista. Jornal do CREMESP. 2008;253:10. Available from: https://www.cremesp.org. $\mathrm{br} /$ ?siteAcao=Jornal\&id=1065. Accessed in 2020 (Jan 13).

24. Oliveira NMF, Barreto B, Furlaneto IP, Neto FCB. Conhecimento de Alunos de Medicina do Centro Universitário do Estado do Pará sobre a Residência Médica [Knowledge about the Medical Residency among students of the Centro Universitário do Estado do Pará]. Rev. Bras. Educ. Med. 2019;43(1):32-8. https://doi.org/10.1590/1981$52712015 \mathrm{v} 43 \mathrm{n} 1 \mathrm{rb} 20180045$.

25. Vanz RL, Perondi F, Boechat CJ. Análise dos serviços de Cirurgia Plástica da Sociedade Brasileira de Cirurgia Plástica. Rev. Bras. Cir. Plást. 2019, 34(2):250-9. http://www.dx.doi.org/10.5935/2177-1235.2019RBCP0141.

26. Marques GH, Martins KPH. Responsabilidade médica e suas implicações na prática clínica. Rev Bioét. 2015;23(1):51-60. https:// doi.org/10.1590/1983-80422015231045.

27. Conselho Federal de Medicina. Resolução CFM no 1.931, de 17 de setembro de 2009. Aprova o Código de Ética Médica. Diário Oficial da União. Brasília, no 183, p. 90, 2009.

28. Gracindo GCL, da Silva Gallo JH, Nunes R. Threats to bioethical principles in medical practice in Brazil: new medical ethics code period. Braz J Med Biol Res. 2018;51(5):e6988. PMID: 29561957; https://doi. org/10.1590/1414-431×20176988.

29. Scheffer MC, Biancarelli A, Cassenote A, et al. Demografia Médica no Brasil 2018. São Paulo: Conselho Regional de Medicina do Estado de São Paulo, Conselho Federal de Medicina, 2018.

30. Shah A, Patel A, Smetona J, Rohrich RJ. Public Perception of Cosmetic Surgeons versus Plastic Surgeons: Increasing Transparency to Educate Patients. Plast Reconstr Surg. 2017;139(2):544e-57e. PMID: 28121896; http://doi.org/10.1097/PRS.0000000000003020.

31. Almeida TA, Pimentel D. Julgamento ético do médico em Sergipe, Brasil. Rev Bioét. 2016;24(1):128-35. https://doi.org/10.1590/198380422016241114. 
Authors' contributions: Mariani PC: conceptualization, data curation,

formal analysis, funding acquisition, investigation, methodology,

resources, validation, writing of original draft and writing review and editing; Constantino CF and Nunes R: supervision, validation, writing of original draft and writing review and editing. All authors approved the final version to be published and agree to be accountable for all aspects of the work, so as to ensure that questions relating to the accuracy and integrity of the work are investigated and resolved

Sources of funding: None

Conflicts of interest: None

Date of first submission: January 27, 2021

Last received: March 28, 2021

Accepted: April 22, 2021

Address for correspondence:

Paulo Cézar Mariani

Rua Hum, 2.366

Jales (SP) - Brasil

CEP 15700-002

Tel. (+55 17) 3632-6410

E-mail:drpaulomariani@hotmail.com 